\title{
UTICAJ PSIHOLOŠKIH KARAKTERISTIKA NA EFIKASNOST IZVOĐENJA ODBRANE OD NAPADA RUKOM
}

\author{
Darko Paspalj ${ }^{1}$
}

\author{
${ }^{1}$ Visoka škola unutrašnjih poslova, Banja Luka, Bosna i Hercegovina
}

\section{SAŽETAK}

Polazeći od činjenice da psihološke karakteristike imaju značajnu ulogu u obuci iz Specijalnog fizičkog obrazovanja, kako za programiranje selekcione dijagnostike tako i za programiranje metoda i sredstava u savladavanju specifičnog nastavnog plana i programa, obavljeno je istraživanje koje je imalo za cilj utvrđivanje uticaja kognitivnih sposobnosti i konativnih karakteristika studenata Visoke škole unutrašnjih poslova na kvalitet izvođenja odbrane od napada rukom u glavu iz programa Specijalnog fizičkog obrazovanja. Istraživanje je provedeno na 70 studenata oba pola treće godine Visoke škole unutrašnjih poslova iz Banje Luke, uzrasta od 21 do 23 godine. Regresiona analiza je pokazala značajan uticaj udruženih varijabli za procjenu kognitivnih sposobnosti i konativnih karakteristika na efikasnost izvođenja odbrane od napada rukom u glavu pri čemu su pojedinačan statistički značajan uticaj u objašnjenju kriterijumske varijable ostvarili: test vizuelne spacijalizacije (S1) namijenjen za procjenu simultane edukcije spacijalnih relacija, test anksioznosti (ALFA) korišćen za procjenu efikasnosti sistema za regulaciju i kontrolu reakcija odbrane i test socijalne neintegrisanosti (ETA) korišćen za procjenu efikasnosti sistema za integraciju regulativnih funkcija, na osnovu čega možemo pretpostaviti da su navedene varijable prediktivne za uspješno izvođenje odbrane od napada rukom iz programa specijalnog fizičkog obrazovanja i da ih treba uzeti u obzir kod planiranja i realizacije nastavnog procesa prilikom rješavanja situaciono-motoričkih problema u poznatim i nepoznatim uslovima.

Ključne riječi: napad rukom, odbrana, psihološke karakteristike.

\section{UVOD}

Imajući u vidu činjenicu da čovjek kao sistem zauzima centralno mjesto u ostvarivanju ciljeva Specijalnog fizičkog obrazovanja, da bi se smisleno moglo uticati na njegov razvoj potrebno je da se zna njegova struktura, način funkcionisanja i njegove adaptivne karakteristike. Specijalno fizičko obrazovanje (u daljem tekstu SFO), kao jedan od uže stručnih predmeta Visoke škole unutrašnjih poslova, ima zadatak da, koristeći različite aktivnosti, oformi adekvatan sistem reagovanja i da osposobi studente za kvalitetno obavljanje poslova koji pored ostalih aktivnosti zahtijevaju i upotrebu sile pri rješavanju problemskih situacija različitog nivoa složenosti. Već zbog same činjenice da obavljanje profesionalnih dužnosti i obaveza podrazumijeva i upotrebu vatrenog oružja, potrebno je da studenti Visoke škole unutrašnjih poslova ovladaju specifičnim znanjima i vještinama koje bi im omogućile da što efikasnije obavljaju svoju djelatnost. Aktuelni model edukacije u SFO, koji se provodi na Visokoj školi unutrašnjih poslova u Banjoj Luci podrazumijeva fazno učenje specifičnih i veoma složenih motoričkih struktura i njihovu primjenu u različitim determinantama i funkcijama cilja. Učenje se odvija kroz osnovnu, usmjerenu i situacionu obuku, pri čemu svaka od faza ima svoje ciljeve i zadatke, koji se ostvaruju kroz određene procese u kojima se uče nove motoričke strukture, prave motorički programi i razvijaju adaptivne karakteristike. Pošto su policijski službenici veoma često meta fizičkog napada od strane jednog ili više lica, posebna pažnja u obuci se poklanja uspješnom izvođenju odbrana i uspostavljanju potpune kontrole nad napa- 
dačima. S obzirom na činjenicu da programiranje odbrane predstavlja veoma kompleksnu misaonu aktivnost koja podrazumijeva sagledavanje i shvatanje prostorno-vremenskih odnosa kao cjeline, uočavanje i prepoznavanje protivnikove akcije, upoređivanje prepoznatog motoričkog programa sa programom koji treba da se realizuje, izbor odgovarajućeg programa, odabiranje i dodavanje odgovarajućih vrijednosti za odabrani program i davanje naredbe za realizaciju, pri čemu rezultat primjene ovih aktivnosti u konkretnim radnim situacijama može da se sažme na binarnu varijablu uspjeh - neuspjeh sa ciljem kontrole ili destrukcije protivnika, pretpostavlja se da kognitivne sposobnosti i konativne karakteristike imaju značajnu ulogu u njenoj realizaciji. Kognitivne sposobnosti imaju uticaja na formiranje programa po kojima funkcionišu regulacioni mehanizmi za programiranje i reprogramiranje motoričkih algoritama odgovornih za pravovremenu, preciznu i brzu primjenu sredstava sile (tehnike za privođenje, odbrane od nenaoružanog i naoružanog napadača, upotreba vatrenog oružja i drugih sredstava sile), pri čemu se efikasnost funkcionisanja pojedinih procesora može procijeniti pravovremenim $i$ adekvatnim donošenjem odluka o djelovanju u uslovima kada mogu da se primijene sredstva sile (dolazi do uske saradnje najviših nivoa centralnog nervnog sistema, odgovornih za prijem i preradu informacija i donošenje odluka o akcijama). S obzirom na to da se sredstva sile primjenjuju u uslovima odbijanja napada, savladavanja otpora ili bjekstva, pred policijskog službenika se postavljaju vrlo visoki zahtjevi: da u djeliću sekunde procijeni sve okolnosti, donese ispravnu odluku i primjeni adekvatno sredstvo sile, svjestan posljedica koje po lice može prouzrokovati upotreba sredstva sile ali i posljedica koje bi proizašle po službu i konkretnu dužnost policajca ako bi se uzdržao od primjene adekvatnog sredstva sile. Taktika upotrebe sredstava sile zahtijeva obučenog, osposobljenog i fizički spremnog profesionalca koji nedvosmisleno poznaje propise i posjeduje sposobnost da brzo prepozna konkretnu situaciju, izvrši pravilnu procjenu i efikasno primijeni zakonsko sredstvo na dozvoljen način. Da bi odlučivanje bilo kvalitetno, treba prepoznati potrebu za donošenjem odluke i biti svjestan vremenskog limita koji postoji pri odlučivanju, a koji je determinisan problemskom situacijom i namjerom sticanja prednosti nad suparnikom. Prije donošenja odluke o djelovanju potrebno je izvršiti analizu informacija koje uzrokuju lica koja sprečavaju pojedina izvršenja (uzrast, pol, broj ljudi, njihove sposobnosti), prostorni i vremenski faktori, zatim vlastita znanja i sposobnosti i zakonsko ispunjenje uslova za primjenu pojedinog sredstva sile, te na osnovu stečenih kriterijuma efikasnosti donijeti odluku o preduzimanju adekvatnih akcija. Iz tog razloga potrebno je osposobiti studente Visoke škole unutrašnjih poslova za primjenu fizičke snage (kao odgovarajućeg i adekvatnog sredstva sile), kako bi ta primjena bila zakonita, pravilna, nepristrasna, efikasna i restriktivna, te da se sa što manje štetnih posljedica obezbijedi obavljanje poslova i zadataka iz nadležnosti policije. Prema Milošević, Mudrić, Jovanović, Amanović i Dopsaj (2005), kognitivne sposobnosti su bitne za efikasnost primjene tehnika iz SFO u borbi, jer policijski službenici treba da prepoznaju akcije protivnika, naprave razliku važnih od manje važnih elemenata kretanja za pojedine situacije, predviđaju promjene kretanja, te da rješavaju različite probleme u kojima se prostorni odnosi predočavaju vizuelnim putem. Takođe, moraju kvalitetno i brzo da utvrđuju međusobne veze elemenata aktuelne situacije i da pravilno i brzo odaberu taktiku postupanja, pri čemu visok radni nivo procesora odgovornih za analizu, programiranje i memorisanje podataka, omogućava i visok nivo efikasnosti primjene različitih tehnika odbrana i napada. S obzirom na činjenicu da u sklopu obuke ne postoje gotovi programi za postupanje u situacionim uslovima, kognitivni procesi su aktuelni u analizi postavljenog problema i formiranju motoričkog odgovora, dok konativne karakteristike bez obzira da li djeluju posredno ili se uzajamno dopunjuju, čine jednu sinergiju ili pak čine određene smetnje kod izvršavanja poslova, izazivajući takva ponašanja koja pospješuju ili onemogućavaju određene procese radi uspostavljanja kontrole nad efektima kretanja. Poznavanje hijerarhijske strukture psiholoških osobina i karakteristika omogućuje nastavniku razumijevanje i predviđanje ponašanja studenta kod rješavanja problemskih situacija različitog nivoa složenosti. Polazeći od pretpostavke da psihološke karakteristike imaju određenu ulogu u obuci Specijalnog fizičkog obrazovanja, a da je u dosadašnjem periodu kroz niz istraživanja potvrđeno da dijelovi ličnosti (kognitivni i konativni domen) ne funkcionišu kao zasebne, izdvojene cjeline, već da su povezane i da djeluju u uzajamnoj sprezi (Momirović i Horga, 1990; Stojiljković, 1995; Vučinić, Popović i Momirović, 1992), obavljeno je istraživanje koje je imalo za cilj da se utvrdi da li, i u kojoj mjeri posmatrane psihološke karakteristike studenata Visoke škole unutrašnjih poslova iz Banja Luke imaju uticaj na efikasnost odbrane od napada rukom u glavu. Rezultati ove vrste istraživanja bili bi od teorijske i praktične vrijednosti za nastavu specijalnog fizičkog obrazovanja jer bi mogli dati mogućnost izbora novih nastavnih oblika i sredstava, uvođenjem u programske struktu- 
re nastavnih sadržaja određenih problemskih situacija, sa kojima se policijski službenici najčešće susreću na terenu, a čiji kriterijum za rješavanje bi bio usklađen sa oblicima ponašanja lica prema kojima treba primjeniti određeno sredstvo sile.

\section{METODE}

\section{Uzorak ispitanika}

Istraživanje je sprovedeno na 70 studenata (44 ispitanika muškog i 26 ispitanika ženskog pola) petog semestra Visoke škole unutrašnjih poslova iz Banje Luke, školske 2007/2008. godine. Uzorkom su bili obuhvaćeni studenti starosnog uzrasta između 21 i 23 godine.

\section{Uzorak varijabli}

Uzorak varijabli u ovom istraživanju podijeljen je na varijable prediktorskog $i$ varijable kriterijumskog sistema. Uzorak prediktorskih varijabli sačinjavao je set od 9 varijabli za procjenu psiholoških karakteristika ispitanika, i to: 3 varijable za procjenu kognitivnih sposobnosti i 6 varijabli za procjenu konativnih karakteristika. Njihov naziv, predmet mjerenja i koeficijenti pouzdanosti dati su u Tabeli 1.

Iz tabele je vidljivo da sve varijable za procjenu psiholoških karakteristika posjeduju potrebne metrijske karakteristike (Momirović, Wolf i Džamonja, 1992). Ispitivanje psiholoških karakteristika uzorka, izvršeno je grupno (od 18 do 25 ispitanika) u posebnim prostorijama koje su ispunjavale standardne uslove grupnog psihološkohg testiranja. Psiholog-ispitivač je u potpunosti ispoštovao proceduru vezanu za provođenje testiranja (objašnjenje cilja istraživanja i davanja opšteg i motivacionog uputstva za rad), pri čemu je vodio protokol o ispitivanju u kom je iznosio sve podatke i događaje koji su mogli da utiču na regularnost ispitivanja. Uvidom u ove protokole može se konstatovati da su sva grupna ispitivanja sprovedena pod regularnim okolnostima i da su svi ispitanici bili motivisani za ispitivanje. Kriterijumsku

\section{TABELA 1}

Naziv, predmet mjerenja i pouzdanost prediktorskih varijabli.

\begin{tabular}{llc}
\hline \multicolumn{1}{c}{ Naziv } & \multicolumn{1}{c}{ Predmet mjerenja } & Pouzdanost \\
\hline IT1 & Efikasnost perceptivnog procesora & .91 \\
\hline AL4 & Efikasnost serijalnog procesora & .94 \\
\hline S1 & Efikasnost paralelnog procesora & .92 \\
\hline EPSILON & Regulacija aktiviteta & .90 \\
\hline HI & Regulacija organskih funkcija & .89 \\
\hline ALFA & Regulacija reakcija odbrane & .92 \\
\hline SIGMA & Regulacija reakcije napada & .90 \\
\hline DELTA & Koordinacijaregulativnih funkcija & .91 \\
\hline ETA & Integracija regulativnih funkcija & .91 \\
\hline
\end{tabular}

varijablu predstavljala je ocjena procjene kvaliteta izvođenja odbrane od napada rukom pravo naprijed u glavu uz iskorak istoimenom nogom, a formirana je izvođenjem prosječne ocjene od strane pet eksperata koji predaju SFO u skali od 5,00 do 10,00. Kriterijum ocjenjivanja je bio sljedeći:

Ocjena 10 (deset) - jednolično i usklađeno izvođenje u optimalnom ritmu tehnika koje zadovoljavaju principe za rješenje konkretne problemske situacije, osnovne biomehaničke principe i omogućavaju bezbjednu i potpunu kontrolu nad napadačem.

Ocjena 9 (devet) - odlično izvođenje tehnika, pri čemu je jedna od komponenti nešto narušena, ali je izvedba još uvijek veoma sigurna.

Ocjena 8 (osam) - dobro izvođenje tehnika, pojava manjih grešaka, pri čemu osnovna struktura elemenata nije narušena, a izvedba je još uvijek sigurna.

Ocjena 7 (sedam) - dosta dobro izvođenje elemenata tehnike, postoji nešto veći broj grešaka, osnovni principi nisu znatno narušeni i postoji određena nesigurnost u izvođenju odbrane.

Ocjena 6 (šest) - osnovna struktura tehnika djelomično poremećena, nedostatak potpune kontrole nad napadačem i nesigurna izvedba.

Ocjena 5 (pet) - loša izvedba, veći nedostaci, struktura kretanja bitno narušena, izrazita nesigurnost.

\section{Statistička obrada podataka}

Obrada podataka izvršena je primjenom programskog paketa SPSS 17.0, pri čemu su deskriptivni sta- 
tistički parametri izračunati za svaku varijablu, dok je za utvrđivanje uticaja sistema prediktorskih varijabli na kriterijumsku varijablu korišćena regresiona analiza.

\section{REZULTATI}

U Tabeli 2 prikazane su deskriptivne vrijednosti za varijable iz prostora kognitivnog sposobnosti i konativnih karakteristika. Pokazalo se da je većina distribucija rezultata prilično dobro grupisana i da nema značajnijih odstupanja od srednjih vrijednosti rezultata. Rezultati Kolmogorov-Smirnov testa pokazali su da većina varijabli ima simetričnu distribuciju. Izuzetak su varijable test konverzivnosti (HI) i test psihoticizma (DELTA), kod kojih distribucija značajno odstupa od Gaussove krive. Najveći raspon rezultata i najveće odstupanje od srednje vrijednosti rezultata zabilježeno je kod varijabli: test anksioznosti (ALFA), test agresivnosti (SIGMA) $\mathrm{i}$ test intro-ekstrovertnosti (EPSILON). Može se uočiti da Skewness veću asimetriju udesno u odnosu na normalnu raspodjelu pokazuje kod varijabli: test konverzivnosti (HI) i test psihoticizma (DELTA), dok je kod ostalih varijabli zabilježena mala ili srednja asimetrija u skladu sa predznakom. Procjenom stepena zakrivljenosti Kurtosis uočeno je da veće vrijednosti spljoštenosti takođe pokazuju varijable: test konverzivnosti (HI) i test psihoticizma (DELTA), dok ostale varijable ne odstupaju od normalne raspodjele.

U Tabeli 3 prikazane su relacije između zavisne varijable odbrana od napada rukom u glavu (ONRG) i udruženih nezavisnih varijabli za procjenu kognitivnih sposobnosti i konativnih karakteristika. Koeficijent multiple korelacije $(R=0,516)$ ukazuje na značajnu saglasnost zavisne varijable sa nezavisnim varijablama. Koeficijent determinacije $\left(R^{2}=0,266\right)$ pokazuje da se $26,6 \%$ ukupnog varijabiliteta zavisno promjenjive može objasniti uticajem udruženih nezavisnih varijabli za procjenu kognitivnih sposobnosti i konativnih karakteristika, dok je preostalih $73,4 \%$ varijabiliteta pod uticajem nekih drugih (neobjašnjenih) faktora.

\section{TABELA 2}

Deskriptivni pokazatelii psiholoških karakteristika ispitanika.

\begin{tabular}{lccccrrrrr}
\hline Varijable & $N$ & Min & Max & \multicolumn{1}{c}{$M$} & \multicolumn{1}{c}{$S D$} & Skew. & Kurt. & \multicolumn{1}{c}{ KS } & \multicolumn{1}{c}{ p } \\
\hline IT1 & 70 & 15 & 31 & 20,97 & 3,467 & 0,560 & $-0,315$ & 1,169 & 0,130 \\
\hline AL4 & 70 & 18 & 40 & 32,63 & 5,525 & $-0,573$ & $-0,560$ & 1,061 & 0,210 \\
\hline S1 & 70 & 14 & 30 & 23,33 & 4,429 & $-0,316$ & $-0,973$ &, 982 & 0,290 \\
\hline EPSILON & 70 & 78 & 150 & 115,74 & 15,014 & $-0,180$ & 0,019 &, 551 & 0,922 \\
\hline HI & 70 & 30 & 75 & 39,33 & 8,810 & 1,501 & 2,931 & 1,458 & $\mathbf{0 , 0 2 9}$ \\
\hline ALFA & 70 & 30 & 106 & 60,47 & 18,981 & 0,378 & $-0,653$ &, 846 & 0,471 \\
\hline SIGMA & 70 & 34 & 109 & 77,26 & 15,048 & $-0,191$ & $-0,131$ &, 665 & 0,769 \\
\hline DELTA & 70 & 30 & 70 & 39,89 & 9,048 & 1,504 & 1,806 & 1,880 & $\mathbf{0 , 0 0 2}$ \\
\hline ETA & 70 & 30 & 82 & 47,21 & 12,225 & 0,708 & $-0,044$ &, 895 & 0,400 \\
\hline
\end{tabular}

Legenda: IT1 - Efikasnost perceptivnog procesora); AL4 - Efikasnost serijalnog procesora;

S1 - Efikasnost paralelnog procesora; EPSILON - Regulacija aktiviteta; HI - Regulacija organskih funkcija; ALFA - Regulacija reakcija odbrane; SIGMA - Regulacija reakcija napada; DELTA - Koordinacija regulativnih funkcija; ETA - Integracija regulativnih funkcija; $N$ - Ukupan broj ispitanika; Min - Minimum; Max - Makimium;

$M$ - Aritmetička sredina; SD - Standardna devijacija; Skew. - Skewnis; Kurt. - Kurtosis; $K-P$ - Konglo-Smirnov test; $p$ - Vjerovatnoća.

Na osnovu vrijednosti F-testa $(2,414)$ i ostvarenog nivoa značajnosti ( $\phi=0.021)$ zaključuje se da se na osnovu psiholoških karakteristika može u izvjesnom stepenu predvidjeti efikasnost izvođenja odbrane od napada rukom pravo naprijed u glavu.

U Tabeli 4 prikazane su vrijednosti Beta koeficijenata koji daju informacije o parcijalnom uticaju nezavisnih varijabli na kriterijumsku varijablu. Stati- stički značajan uticaj ostvarile su varijable: test vizuelne spacijalizacije (S1) namijenjen za procjenu simultane edukcije spacijalnih relacija kod kojih su procesi utvrđivanja i restrukturiranja nezavisni od prethodno stečene količine informacija, test anksioznosti (ALFA) korišćen za procjenu efikasnosti sistema za regulaciju i kontrolu reakcija odbrane $i$ test socijalne neintegrisanosti (ETA) korišćen za procjenu efikasnosti siste- 


\section{TABELA 3}

Regresiona analiza udruženih prediktora i odbrane od napada rukom.

\begin{tabular}{ccccc}
\hline$R$ & $R^{2}$ & $S D$ & $F$ & $p$ \\
\hline 0,516 & 0,266 & 0,93272 & 2,414 & $\mathbf{0 , 0 2 1}$ \\
\hline
\end{tabular}

Legenda: $\mathbf{R}$ - Koeficijent multiple korelacije; $\boldsymbol{R}^{2}$ - Koeficijent determinacije; $S D$ - Standardna devijacija; $F$ - F-test; $\boldsymbol{p}$ - Vjerovatnoća.

\section{TABELA 4}

Regresiona i odbrane udrǔ̌enih prediktora odbrane od napada rukom.

\begin{tabular}{lccccc}
\hline \multicolumn{1}{r}{ Model } & $\mathrm{B}$ & $\mathrm{SE}$ & $\beta$ & $t$ & $p$ \\
\hline (Constant) & $\mathbf{6 , 1 8 8}$ & 1,614 & & & \\
\hline IT1 & 0,004 & 0,035 & 0,014 & 0,110 & 0,913 \\
\hline AL4 & $-0,010$ & 0,022 & $-0,056$ & $-0,460$ & 0,647 \\
\hline S1 & 0,064 & 0,029 & 0,281 & 2,231 & $\mathbf{0 , 0 2 9}$ \\
\hline EPSILON & $-0,006$ & 0,009 & $-0,092$ & $-0,700$ & 0,487 \\
\hline HI & $-0,015$ & 0,023 & $-0,133$ & $-0,654$ & 0,515 \\
\hline ALFA & 0,034 & 0,010 & 0,635 & 3,374 & $\mathbf{0 , 0 0 1}$ \\
\hline SIGMA & 0,014 & 0,009 & 0,203 & 1,541 & 0,128 \\
\hline DELTA & 0,017 & 0,020 & 0,149 & 0,820 & 0,415 \\
\hline ETA & $-0,055$ & 0,022 & $-0,663$ & $-2,506$ & $\mathbf{0 , 0 1 5}$ \\
\hline
\end{tabular}

Legenda: IT1 - Efikasnost perceptivnog procesora; AL4 - Efikasnost serijalnog procesora;

S1 - Efikasnost paralelnog procesora; EPSILON - Regulacija aktiviteta; HI - Regulacija organskih funkcija; ALFA - Regulacija reakcija odbrane; SIGMA - Regulacija reakcija napada; DELTA - Koordinacija regulativnih funkcija; ETA - Integracija regulativnih funkcija; B - Beta koeficijent; $S D$ - Standardna devijacija; $t$ - Studenova t distribucija; $p$ - Vjerovatnoća.

ma za integraciju regulativnih funkcija, čija je funkcija da integriše konativne regulativne procese pod vidom stukture socijalnog polja.

\section{DISKUSIJA}

Struktura primijenjenih antropoloških obilježja u ovom istraživanju u potpunosti je u skladu sa potrebom identifikacije i razvoja sposobnosti, osobina i znanja studenata koja su značajna za metodičko oblikovanje nastavnog procesa posebno u segmentu primjene naučenog kod posmatranog motoričkog problema. Rezultati ovog istraživanja pokazali su značajan uticaj udruženih varijabli za procjenu kognitivnih sposobnosti i konativnih karakteristika na efikasnost izvođenja odbrane od napada rukom u glavu, pri čemu su pojedinačan statistički značajan uticaj u objašnjenju kriterijumske varijable ostvarili: test vizuelne spacijalizacije (S1) namijenjen za procjenu simultane edukcije spacijalnih relacija, test anksioznosti (ALFA) korišćen za procjenu efikasnosti sistema za regulaciju i kontrolu reakcija odbrane i test socijalne neintegrisanosti (ETA) korišćen za procjenu efikasnosti sistema za integraciju regulativnih funkcija, na osnovu čega možemo pretpostaviti da su navedene varijable prediktivne za uspješno izvođenje odbrane od napada rukom iz programa Specijalnog fizičkog obrazovanja i da ih samim tim treba uzeti u obzir kod planiranja i realizacije nastavnog procesa prilikom rješavanja situaciono-motoričkih problema u poznatim i nepoznatim uslovima. Objašnjenje dobijenih rezultata treba prije svega potražiti u dobro razvijenoj sposobnosti pretrage vizuelnog polja i lociranja objekata u njemu, niskom intenzitetu mehanizma za regulaciju i kontrolu reakcija odbrane što uslovljava dobru regulaciju anksioznosti, vjerovatno zato što su ispitanici u toku uvježbavanja datog motoričkog problema unaprijed znali na koji način će partner izvršiti motoričku kretnju pa su na taj način stekli samopouzdanje i međusobno povjerenje, pri čemu kod realizacije tehnika napada i odbrana nije postojala bojazan od povrijeđivanja jer su ispitanici „čuvali““ 
jedni druge. Treba ukazati da je kod izvođenja udarca rukom u glavu primjećeno znatno odstupanje od realnog napada te da su ispitanici prilikom rješavanja problemske situacije bili veoma sigurni jer su situaciju rješavali u poznatim uslovima, kojom prilikom su primjenjivali već usvojena rješenja, pri čemu su preferirali ,sigurnije“ tehnike koje nose manji rizik prilikom njihove realizacije, što je olakšalo realizaciju motoričkih programa pri izvođenju tehnika odbrana i kontranapada. S obzirom na to da je u pitanju udarac rukom u glavu, kognitivno učešće kod izvođenja odbrane moglo bi se objasniti i ćinjenicom da se u takvim situacijama čovjek refleksno (mogli bismo reći, bez učešća svijesti, ako je to uopšte moguće) zaštićuje, pa nije ni za očekivati neki značajan kognitivni proces prije i u toku izvođenju tehnike odbrane, već bi se prije moglo govoriti o sposobnosti kontrole emocija (misli se, prije svega, na strah i uzbuđenje). Dalje, razlog ovakvim rezultatima je moguće potražiti i u strukturi izvođenja samog udarca rukom. Naime, udarac rukom karakteriše terminalni pokret koji ima svoj početak i kraj a koji se izvodi inicijalnim impulsom sile, kao jedna inicijalna balistička faza, koju prati faza reakcije bazirana na trenutnoj brzini i položaju. Prvi dio pokreta se vrši putem kontrole inicijalnog impulsa pri čemu njegove kasnije sekvence s obzirom na veliku brzinu izvođenja nije moguće korigovati. U prilog ovoj tvrdnji ide i činjenica da su udarci rukom genetski kodirani prirodni pokreti pa samim tim ne zahtijevaju značajan kognitivni naboj, poput odbrane koju u našem slučaju karakteriše više refleksna nego naučena kretnja, što je potpuno razumljivo s obzirom na relativno mali broj nastavnih časova i ponavljanja.

Da bismo imali potpuniju sliku o odnosu psiholoških karakteristika i efikasnosti izvođenja odbrane od napada rukom u glavu potrebno je sagledati istraživanja navedenih karakteristika koja su sprovedena na sličnom uzorku ispitanika. Mudrić i Jovanović (2001) su na uzorku od 102 studenta petog semestra Više škole unutrašnjih poslova iz Zemuna izvršili istraživanje kognitivnih sposobnosti i konativnih karakteristika sa ciljem formiranja modela psiholoških karakteristika studenata Više škole unutrašnjih poslova. Dobijeni rezultati govore o psihološkom profilu studenata kod kojih je izražen visok faktor kristalizovane inteligencije, savjesnosti, pouzdanosti, odgovornosti, emocionalne stabilnosti, upornosti, samouvjerenosti i spokojnosti. Ukoliko se uporede dobijeni rezultati pomenutog istraživanja sa rezultatima našeg istraživanja, vidljivo je da su dobijeni veoma slični rezultati. Objašnjenje se može potražiti u činjenici da su i jedni i drugi ispitanici prilikom konkursa za prijem na školovanje bili podvrgnuti gotovo istim ili sličnim testovima za procjenu psiholoških karakteristika, kao i da su u toku školovanja izučavali identične nastavne sadržaje koji se realizuju u istim ili sličnim uslovima. Kasum i Bačanac (2007) su istraživali povezanost pojedinih psiholoških karakteristika vrhunskih rvača i njihovih glavnih poentirajućih tehnika, kojom prilikom su ustanovili da je izbor dominantne tehnike u rvanju povezan sa određenim psihološkim svojstvima rvača. Utvrđeno je da rvači koje karakteriše viši nivo sportske takmičarske anksioznosti biraju i koriste poentirajuće tehnike koje u sebi nose veći rizik i donose manju rezultatsku neizvjesnost. Ovo je u skladu sa rezultatima istraživanja koje je proveo Popović (1990) u kome je utvrdio da za izvođenje požrtvovnih tehnika u judou, veliko učešće imaju konativne karakteristike koje su definisane anksioznim tendencijama i opsesivnošću. Međutim, rezultati ovog istraživanja, kada je u pitanju nivo anksioznosti, se razlikuju od rezultata navedenih istraživanja, što je i razumljivo s obzirom na to da su naši ispitanici odbrane izvodili u poznatim uslovima, dok su rvači i džudisti radili sportske borbe u cilju ostvarenja takmičarskih rezultata, pa je kod njih i očekivano znatno strahovanje u smislu postizanja takmičarskog uspjeha. Dakle, ima li se u vidu činjenica da su predmet ovog istraživanja bili studenti Visoke škole unutrašnjih poslova, koji su u procesu učenja odbrane od napada rukom aktivnost izvodili više puta u poznatim uslovima, realno je pretpostaviti da su stekli međusobno povjerenje i sigurnost kod izvođenja odbrane, pa je i razumljivo da se nije pojavio strah od povrede ili gubitka poena, kao mogući uzrok anksioznog ponašanja.

Blažević i Malacko (2007) su proveli istraživanje s ciljem utvrđivanja uticaja sistema kognitivnih sposobnosti na pojedinačne specifične motoričke sposobnosti kod vrhunskih boksera. Primjenom regresione analize dobili su rezultate prema kojima je test AL - 4 imao statistički značajan uticaj na sve kriterijumske varijable, dok je test IT - 1 imao uticaja na brzinu izvođenja kombinovanih udaraca na vreći, izvođenje sunožnih poskoka za 10 sekundi, izvođenje lijevog i desnog aperkata $i$ izvođenje serije od 100 kombinovanih udaraca na ruku trenera. Kada se uporede njihovi rezultati sa rezultatima ovog istraživanja vidjeće se da se oni bitno razlikuju. Naime, navedeni autori su istraživali kombinaciju sukcesivnih tehnika po zadanom obrascu, pri čemu su ispitanici sami procjenjivali efekat svakog izvedenog pokreta, dok su u ovom istraživanju ispitanici morali da pristižuće informacije istovremeno obrađuju pa je i razumljivo da značajnu ulogu u odbrani od udarca rukom u glavu ima sposobnost procjene simultane edukcije 
spacijalnih relacija kod kojih su procesi utvrdivanja i restrukturiranja nezavisni od prethodno stečene količine informacija. Iz svega navedenog vidljivo je da su psihološke karakteristike uz ostale karakteristike i sposobnosti veoma važna determinanta koja može da odlučuje o konačnom uspjehu u integralnom obrazovanju studenata Visoke škole unutrašnjih poslova pri rješavanju situaciono -motoričkih problema različitog nivoa složenosti u poznatim i nepoznatim uslovima.

\section{ZAKLJUČAK}

Imajući u vidu da su pored tehnike, taktike i fizičke pripreme, psihološki regulatorni mehanizmi veoma bitni za konačan uspjeh, a na osnovu činjenice da se različiti pojedinci međusobno razlikuju po svojim obilježjima, nameće se potreba da nastava specijalnog fizičkog obrazovanja treba da bude u funkciji individualnih sposobnosti i osobina studenata. Iz tog razloga je provedeno istraživanje na studentima treće godine Visoke škole unutrašnjih poslova u Banjoj Luci, koje je imalo za cilj da se utvrdi da li i u kojoj mjeri posmatrane psihološke karakteristike studenata Visoke škole unutrašnjih poslova iz Banja Luke imaju uticaj na efikasnost odbrane od napada rukom u glavu. $\mathrm{Na}$ osnovu dobijenih rezultata regresionom analizom utvrđeno je da psihološke karakteristike imaju statistički značajan uticaj na efikasnost izvođenja odbrane od napada rukom u glavu, pri čemu je moguće zaključiti da ispitanici koji su imali bolje razvijenu sposobnost pretrage vizuelnog polja i lociranja objekata u njemu i dobru regulaciju anksioznosti su bili efikasniji u izvođenju odbrana od napada rukom u glavu. Dakle, rezultati ovog istraživanja bi sa aspekta metododike obučavanja mogli dati mogućnost izbora novih nastavnih oblika i sredstava, uvođenjem u programske strukture nastavnih sadržaja SFO, određenih problemskih situacija koje bi se rješavale usklađivanjem mogućih rješenja sa psihološkim karakteristikama i sposobnostima svakog pojedinca. S obzirom na to da su istraživanja ove problematike veoma rijetka u ovom prostoru, moguće je da ovo istraživanje podstakne i druga slična istraživanja koja bi mogla doprinijeti efikasnosti u obučavanju ali i u selekciji kandidata.

\section{LITERATURA}

Blažević, S., \& Malacko, J. (2007). Evaluacija doprinosa kognitivnog statusa boksača uspjehu u izvođenju specifičnih motoričkih struktura Evaluation of the contribution of cognitive boxer success in the execution of specific motor structure]. Acta Kinesiologica, 1(2), 12-17.

Kasum, G., \& Bačanac, Lj. (2007). Povezanost pojedinih psiholoških karakteristika vrhunskih rvača i njihovih glavnih poentirajućih tehnika [Connection between some psychological characteristics of elite wrestlers and their main scoring techniques]. Fizicke a kultura, 61(1-2), $1-12$.

Milošević, M., Mudrić, R., Jovanović, S., Amanović, Đ., \& Dopsaj, M. (2005). Konstituisanje sistema za upravljanje trenutnim $i$ kumulativnim edukativnim $i$ trenažnim efektima (upravljanje u SFO)

[Constituting system for managing current and cumulative educational and physical training effects (management SFO)]. Beograd, RS: Monografija iz istraživačkog projekta.

Momirović, K., \& Horga, S. (1990). Povezanost rezultata u testovima intelektualnih sposobnosti i osobina ličnosti [Correlation of results of tests of intellectual abilities and personality factors]. Primijenjena psibologïa, 11(1), 31-36.

Momirović, K., Wolf, B., \& Džamonja, Z. (1992). Kiberneticke baterija konativnih testova [Cybernetic battery of cognitive tests]. Beograd, RS: Savez društva psihologa Srbije, Centar za primijenjenu psihologiju.

Mudrić, R., \& Jovanović, S. (2001). Model psiholoških karakteristika studenata VŠUP Model psychological characteristics of students of College of Interior]. Treci zbornik radova nastavnika Više škole unutrašnjih poslova (pp. 6380). Beograd, RS: Viša škola unutrašnjih poslova.

Popović, D. (1990). Struktura kognitivnih sposobnosti judista [The structure of cognitive abilities of judokes]. Scientific Congress, Valorisation of Program's Effects in Physical Culture. Novi Sad, RS: Fakultet fizičke kulture.

Stoiljković, S. (1995). Odnosi između inteligencije i ličnosti Relationship between intelligence and personality]. Psibologija, 1-2, 29-43.

Vučinić, B., Popović, B. V., \& Momirović, K. (1992). Prilog poznavanju odnosa između intelektualnih sposobnosti i osobina ličnosti [Contribution to the knowledge of the relationship between intellectual abilities and personality factors]. Zbornik instituta za kriminološka i sociološka istraživanja, 21(1-2), 178200.

Wolf, B., Momirović, K., \& Džamonja, Z. (1992). Baterija testova inteligencije [Battery of intelligence tests]. Beograd, RS: Savez društva psihologa Srbije, Centar za primijenjenu psihologiju. 
Primljeno: 10. septembar 2013. godine Izmjene primljene: 2. decembar 2013. godine Odobreno: 23. decembar 2013. godine

Korespondencija: Dr Darko Paspalj Buluvera V. Živojina Mišića 10A 78000 Banja Luka Bosnia and Herzegovin Telefon: 0038766240357 E-mail:dpaspalj@yahoo.com 